\title{
A Novel Disease of Big-Leaf Mahogany Caused by Two Fusarium Species in Mexico
}

R. Santillán-Mendoza and S. P. Fernández-Pavía, Laboratorio de Patología Vegetal, IIAF, Universidad Michoacana de San Nicolás de Hidalgo (UMSNH), Km. 9.5 Carr. Morelia-Zinapécuaro, Michoacán 58880, México; K. O’Donnell, Mycotoxin Prevention and Applied Microbiology Research Unit, United States Department of Agriculture-Agricultural Research Service, National Center for Agricultural Utilization Research, Peoria, IL 61604; R. C. Ploetz, Department of Plant Pathology, Tropical Research and Education Center, University of Florida, Homestead 33031-3314; R. Ortega-Arreola, Campo Experimental Tecomán, Instituto Nacional de Investigaciones Forestales, Agrícolas y Pecuarias, Tecomán, Colima 28100, México; G. Vázquez-Marrufo, Centro Multidisciplinario de Estudios en Biotecnología, FMVZ, UMSNH; J. Benítez-Malvido, Instituto de Investigaciones en Ecosistemas y Sustentabilidad, Universidad Nacional Autónoma de México, Antigua Carretera a Pátzcuaro No. 8701, Ex Hacienda de San José de la Huerta, Morelia, Michoacán 58190, Mexico; J. C. MonteroCastro, Facultad de Biología, UMSNH, Cd. Universitaria, Morelia, Michoacán 58060, México; and A. Soto-Plancarte, and G. RodríguezAlvarado, ${ }^{\dagger}$ Laboratorio de Patología Vegetal, IIAF, UMSNH

\begin{abstract}
Big-leaf mahogany (Swietenia macrophylla) is valued for its high-quality wood and use in urban landscapes in Mexico. During surveys of mangoproducing areas in the central western region of Mexico, symptoms of malformation, the most important disease of mango in the area, were observed on big-leaf mahogany trees. The objectives of this research were to describe this new disease and determine its cause. Symptoms on big-leaf mahogany at four sites in Michoacán, Mexico resembled those of the vegetative phase of mango malformation, including compact, bunched growth of apical and lateral buds, with greatly shortened internodes and small leaves that curved back toward the supporting stem. Of 163 isolates that were recovered from symptomatic tissues, most were

identified as Fusarium pseudocircinatum $(n=121)$ and $F$. mexicanum ( $n=39$ ) using molecular systematic data; two isolates represented unnamed phylospecies within the $F$. incarnatum-equiseti species complex (FIESC 20-d and FIESC 37-a) and another was in the $F$. solani species complex (FSSC $25-\mathrm{m}$ ). However, only $F$. mexicanum and $F$. pseudocircinatum induced malformation symptoms on 14-day-old seedlings of big-leaf mahogany. The results indicate that $F$. mexicanum and $F$. pseudocircinatum, previously reported in Mexico as causal agents of mango malformation disease, also affect big-leaf mahogany. This is the first report of this new disease and the first time that $F$. mexicanum was shown to affect a host other than mango.
\end{abstract}

Malformation is one of the most important diseases of mango (Mangifera indica L.) worldwide (Ploetz 2001). Mango malformation disease (MMD) affects vegetative parts of the tree and, via its impact on flowers, reduces fruit set and yield (Ploetz and Freeman 2009). The disease is caused by several species in the Fusarium fujikuroi species complex (O'Donnell et al. 1998). They include F. mangiferae Britz, M. J. Wingf. \& Marasas (Britz et al. 2002), reported in China, Egypt, Florida (United States), India, Israel, Malaysia, Oman, South Africa, Spain, and Sri Lanka (Freeman et al. 2014b); F. sterilihyphosum Britz, Marasas \& M. J. Wingf., detected in South Africa (Britz et al. 2002) and Brazil (Lima et al. 2012); F. mexicanum T. Aoki, S. Freeman, Otero-Colina, Rodríguez-Alvarado, FernándezPavía, Ploetz \& O’Donnell, described in Mexico (Otero-Colina et al. 2010; Rodríguez-Alvarado et al. 2008); F. proliferatum (Matsush.) Nirenberg ex Gerlach \& Nirenberg, reported in China (Zhan et al. 2010); F. tupiense C. S. Lima, Pfenning \& J. F. Leslie, initially

${ }^{\dagger}$ Corresponding author: G. Rodríguez-Alvarado;

E-mail: gra.labpv@gmail.com

Funding: R. Santillán-Mendoza thanks Consejo Nacional de Ciencia y Tecnología (CONACYT) for providing a doctoral scholarship (number 258550)

Mention of trade names or commercial products in this publication is solely for the purpose of providing specific information and does not imply recommendation or endorsement by the U.S. Department of Agriculture. USDA is an equal opportunity provider and employer.

*The $\boldsymbol{e}$-Xtra logo stands for "electronic extra" and indicates that one supplementary figure is published online.

Accepted for publication 10 April 2018.

C 2018 The American Phytopathological Society reported in Brazil (Lima et al. 2012) and later in Senegal (Senghor et al. 2012) and Spain (Crespo et al. 2016); and F. pseudocircinatum O'Donnell \& Nirenberg, initially reported in Mexico (Freeman et al. 2014a) and later in the Dominican Republic (García-López et al. 2016). Foliar and vegetative symptoms that are induced on mango by these species are similar (Cohen et al. 2017). They include deformation of floral panicles with short primary and secondary axes, an increase in the number of male flowers and sterile hermaphrodite flowers, and shortened internodes with small and bristle-like leaves (Ploetz and Freeman 2009).

To date, only $F$. mexicanum and $F$. pseudocircinatum have been shown to cause MMD in Mexico, although other species have been isolated from malformed tissues (Otero-Colina et al. 2010). F. mexicanum, represented by a few clonal lineages, was most prevalent in mango orchards and commercial mango nurseries in the central western region of the country (Betancourt-Resendes et al. 2012; Otero-Colina et al. 2010; Rodríguez-Alvarado et al. 2012; Soto-Plancarte et al. 2015). In spite of the importance of MMD in Mexico, little is known about the ecology of the pathogens and effective disease management. Although two of the MMD agents, F. proliferatum and F. pseudocircinatum, affect multiple hosts (Abdalla et al. 2000; Elmer 1995; Logrieco et al. 1995; Nirenberg and O'Donnell 1998; Ocamb et al. 2002), other species that cause MMD (i.e., F. mangiferae, F. sterilihyphosum, $F$. mexicanum, and $F$. tupiense) are only known to affect mango.

The Mexican government recently provided economic incentives to increase production of high-value timber species in the country, including big-leaf mahogany (Swietenia macrophylla King, Meliaceae) (CONAFOR 2017). However, despite the interest in increased production, little is known about the factors that impact this important tree. Other than the shoot borer moth, Hypsipyla grandella Zeller (PérezSalicrup and Esquivel 2008; Rodan et al. 1992), scant information has been published on problems that affect this species. Several fungi have been isolated from trees of a related species, S. mahagoni L. (Jacq.) (West Indian mahogany), some of which were associated with "galls" or "witches' broom" (Alfieri et al. 1994; Farr et al. 1989). However, 
there is no record that of any of these fungi have been tested as pathogens on this tree.

Three geographically disjunct, interfertile neotropical species are recognized in the genus Swietenia: (i) big-leaf mahogany is naturally distributed from central Mexico, through Central America, and to the southern part of the Amazon basin in Bolivia and Brazil (Mayhew and Newton 1998; Rodan et al. 1992); (ii) Pacific coast mahogany, S. humilis Zuccarini, is endemic to the Pacific coast of Central America; and (iii) West Indian mahogany is native to Cuba, Hispaniola, Jamaica, the Bahamas, and the Florida Keys (Rodan et al. 1992). Of these species, big-leaf mahogany has the highest trade value (Rodan et al. 1992). Unfortunately, it has been harvested extensively in South and Central America (Gillies et al. 1999). Drastic reductions in populations of big-leaf and Pacific coast mahogany have occurred during the last 60 years in Costa Rica (Navarro et al. 2003), and concern for the conservation status of big-leaf mahogany resulted in its inclusion in Appendix II of the Convention on International Trade in Endangered Species of Wild Fauna and Flora in 2003 (Grogan and Barreto 2005).

We discovered symptoms of malformation on big-leaf mahogany in mango-producing areas in the central western region of Mexico in 2012. In the present study, we describe this previously unrecognized disease. We report molecular systematic data used to identify the Fusarium spp. that were associated with this disease, and discuss the completion of Koch's postulates for two of the species, F. mexicanum and F. pseudocircinatum.

\section{Materials and Methods}

Collecting sites and sampling strategy. During 2014 and 2015, big-leaf mahogany trees with malformation symptoms were sampled in four municipalities in the state of Michoacán, Mexico. The collecting sites were adjacent to mango-producing areas in Apatzingán $\left(19^{\circ} 00^{\prime}\right.$ $\left.31.4^{\prime \prime} \mathrm{N}, 102^{\circ} 13^{\prime} 45.5^{\prime \prime} \mathrm{W}\right)$, Parácuaro $\left(19^{\circ} 04^{\prime} 10.8^{\prime \prime} \mathrm{N}, 102^{\circ} 14^{\prime} 56.5^{\prime \prime} \mathrm{W}\right)$, Gabriel Zamora $\left(19^{\circ} 05^{\prime} 34.3^{\prime \prime} \mathrm{N}, 102^{\circ} 03^{\prime} 28.1^{\prime \prime} \mathrm{W}\right)$, and La Huacana $\left(18^{\circ} 57^{\prime} 18.6^{\prime \prime} \mathrm{N}, 101^{\circ} 48^{\prime} 21.6^{\prime \prime} \mathrm{W}\right)$ (Fig. 1). The four collecting areas have an average annual temperature of $28^{\circ} \mathrm{C}$, the average rainfall ranges from 476 to $600 \mathrm{~mm}$, and the mean height above sea level ranges from 392 to $600 \mathrm{~m}$ (INEGI 2009). Malformed tissues (Fig. 2), 5 to $10 \mathrm{~cm}$ in diameter, were excised from four equidistant sectors of each sampled tree and stored in labeled plastic bags on ice for transportation to the laboratory. Samples were also taken from the tips of healthy branches of symptomless big-leaf mahogany trees at the collecting sites in Parácuaro and Gabriel Zamora.

Isolations from malformed tissue of big-leaf mahogany trees. Fungal isolates were obtained following standard protocols (SotoPlancarte et al. 2015). Small subsamples $\left(2.0 \mathrm{~cm}^{2}\right)$ were cut from an area without necrosis from each of the four tissues excised from each tree. These were placed into a 50-ml conical tube (Corning, Corning, NY) containing $20 \mathrm{ml}$ of water plus $1 \%$ powdered detergent (Roma, Fábrica de Jabón La Corona, Xalostoc, Mexico) for $10 \mathrm{~min}$ to remove dirt and insects, immersed in $0.6 \%$ sodium hypochlorite for $1 \mathrm{~min}$, rinsed three times in sterile water, blotted dried on sterile paper, and pooled; 10 to $125-\mathrm{mm}^{2}$ samples were transferred to 100 by-15-mm Petri plates containing peptone-pentachloronitrobenzene agar (Leslie and Summerell 2006) supplemented with ampicillin (Sigma-Aldrich, St. Louis) at $0.7 \mathrm{~g} /$ liter and rifampicin (SigmaAldrich) at $10 \mathrm{mg} /$ liter. Plates were incubated at $25^{\circ} \mathrm{C}$ for 24 to $48 \mathrm{~h}$. Emerging fungal colonies were transferred to plates containing $2 \%$ water agar, incubated in the dark for $48 \mathrm{~h}$, and purified by transferring hyphal tips to Petri plates containing synthetic low nutrient

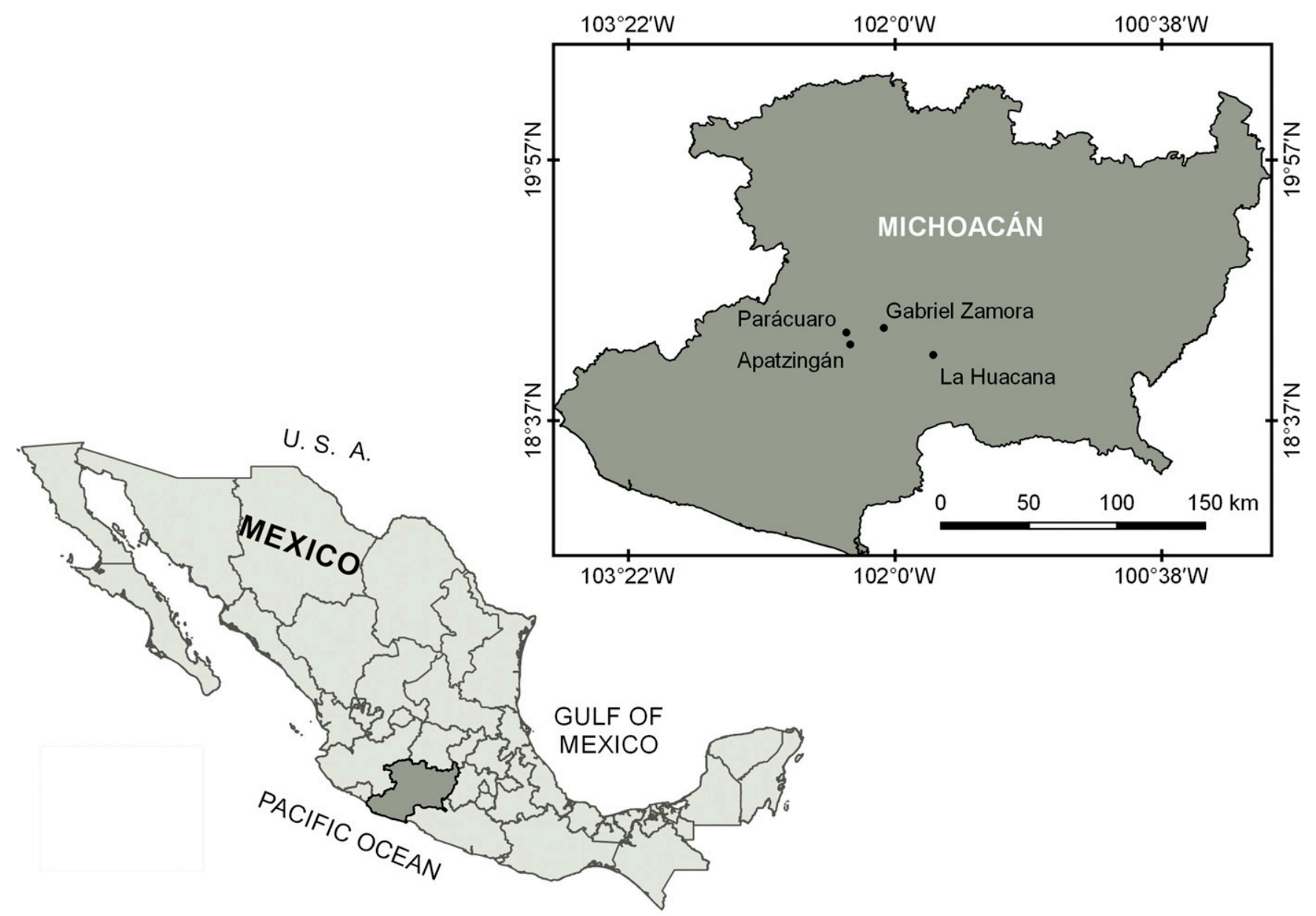

Fig. 1. Map of Michoacán, Mexico, showing areas where big-leaf mahogany trees with malformation symptoms were sampled. Michoacán is located in the central western region of Mexico. 
agar (SNA) (Nirenberg and O'Donnell 1998). Isolates were incubated under cool-white and black lights at $25^{\circ} \mathrm{C}$ for 7 days to induce sporulation, and 163 Fusarium isolates were recovered. These were stored at $-80^{\circ} \mathrm{C}$ in $15 \%$ glycerol in the laboratory of Kerry O'Donnell or deposited in the Agricultural Research Service Culture Collection Northern Regional Research Laboratory (NRRL), Peoria, IL, where they are available upon request (https://nrrl.ncaur.usda.gov/).

Genomic DNA extraction. Mycelial mats from 7-day-old static cultures grown in potato dextrose broth $\left(25^{\circ} \mathrm{C}\right)$ were pelleted by centrifuging for $3 \mathrm{~min}$ and then rinsed with sterile distilled water. DNA was extracted using a cetyltrimethylammonium bromide (CTAB; Sigma-Aldrich) procedure described by Leslie and Summerell (2006), with modifications. Briefly, ground mycelium was incubated in lysis buffer at $65^{\circ} \mathrm{C}$ for $1 \mathrm{~h}$, and absolute ethanol was used instead of isopropanol (2-propanol). The DNA concentration was determined in a spectrophotometer (Nanodrop; Thermo Scientific, Waltham, MA).

Internal simple sequence repeat analysis. Internal simple sequence repeats (ISSR) were analyzed for the 163 fusaria that were recovered, utilizing the following three oligonucleotides that were designed by Liu et al. (2014): 809, 812, and 891. Representative strains of the following MMD pathogens were included as references in the ISSR analysis: F. mangiferae (Coleção Micológica de Lavras [CML] 409), F. mexicanum (MXMIC-698), F. sterilihyphosum (CML 280), and $F$. tupiense (CML 345). Polymerase chain reactions (PCR) were carried out in a total volume of $13 \mu \mathrm{l}$ using GoTaq Hot Start (Promega Corp., Madison, WI), $100 \mathrm{pmol}$ of one ISSR primer, and $3 \mu \mathrm{l}$ of DNA (12 ng/ $\mu \mathrm{l})$. PCR were conducted in an Eppendorf Mastercycler Gradient (Eppendorf, Hauppauge, NY) using the following program: an initial denaturation cycle at $94^{\circ} \mathrm{C}$ for $2 \mathrm{~min}$ and 35 cycles of $94^{\circ} \mathrm{C}$ for $1 \mathrm{~min}$, $48^{\circ} \mathrm{C}$ for $1 \mathrm{~min}$, and $72^{\circ} \mathrm{C}$ for $2 \mathrm{~min}$. The amplification ended with a final elongation step at $72^{\circ} \mathrm{C}$ for $7 \mathrm{~min}$. The reaction products $(5 \mu \mathrm{l})$ were analyzed in $2 \%$ agarose gels electrophoresed at $50 \mathrm{~V}$ for $100 \mathrm{~min}$, stained with ethidium bromine, and visualized using a UV transilluminator (UVP, Lab-Tech, Guadalajara, MX).

PCR assay for mating type. Mating type (MAT) idiomorphs were determined with GFmatla and GFmat1b (MAT1-1) and Gfmat2c and Gfmat2d (MAT1-2) primers reported by Steenkamp et al. (2000). MAT1-1 and MAT1-2 amplicons generated with the primers were 200 and $800 \mathrm{bp}$, respectively.

Multilocus molecular phylogenetic identification of the fungal isolates. Mycelium of isolates grown in yeast-malt broth was harvested after 3 to 4 days, freeze dried, and processed with a CTAB protocol to extract genomic DNA (Gardes and Bruns 1993). Portions of translation elongation factor $1-\alpha$ (TEF1), RNA polymerase largest subunit $(R P B 1), \beta$-tubulin, and the nuclear ribosomal internal transcribed spacer region and $5^{\prime}$ end of the nuclear ribosomal large subunit were PCR amplified and sequenced as described previously (O'Donnell and Cigelnik 1997; O'Donnell et al. 2010; White et al. 1990). Amplicons were sequenced with BigDye 3.1 (Applied Biosystems, Foster City, CA), purified with BigDye Xterminator, and run on an ABI 3730 genetic analyzer. Sequence chromatograms were edited with Sequencher 5.2.4 (Gene Codes Corp., Ann Arbor, MI), exported as NEXUS files, and manually edited to improve the alignments prior to conducting maximum-parsimony (MP) and maximumlikelihood (ML) phylogenetic analyses, respectively, with PAUP* $4.0 \mathrm{~b} 10$ (Swofford 2003) and GARLI 2.01 (Zwickl 2006). DNA sequences were deposited in the National Center for Biotechnology Information GenBank under accession numbers KX870032 to KX870045, KX912230 to KX912243, and MG838022 to MG838111.

Pathogenicity experiments. Seeds were removed from mature fruit of big-leaf mahogany trees in Gabriel Zamora and stored at $25^{\circ} \mathrm{C}$. The wing and outer integuments were removed prior to incubating the seed in plastic containers with moist sterile paper under cool-white light at $25^{\circ} \mathrm{C}$. Most seed germinated within 4 to 6 days.

Isolates were cultivated on SNA at $25^{\circ} \mathrm{C}$ under continuous white and black fluorescent light for 14 days. Fourteen-day-old seedlings were immersed in a suspension of each isolate at $4.9 \times 10^{6}$ conidia/ml for $12 \mathrm{~h}$ at $25^{\circ} \mathrm{C}$, before they were planted in pots with a sterile mixture of peat moss and perlite (1:1). Plants were grown at $25^{\circ} \mathrm{C}$ under a diurnal cycle of $16 \mathrm{~h}$ of light and $8 \mathrm{~h}$ of darkness for 1 week, then transferred to a greenhouse and inspected regularly for symptoms for 4 months. The identity of Fusarium isolates that

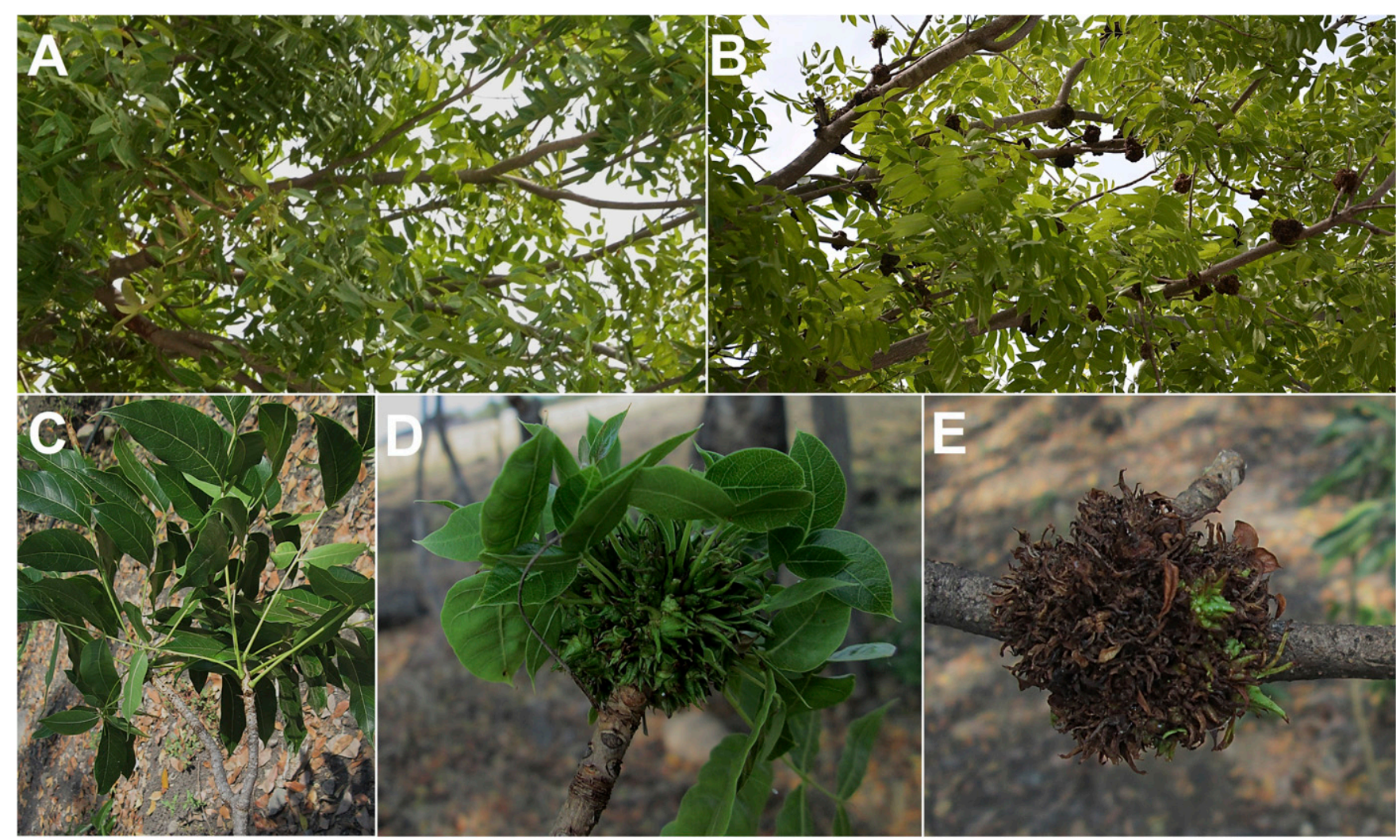

Fig. 2. Malformation symptoms on big-leaf mahogany trees. A, Big-leaf mahogany trees with asymptomatic branches. B, Branches with vegetative malformation. C, Branch with healthy lateral and terminal shoots. D, Young branch with vegetative malformation. E, Mature branch with vegetative malformation. 
were recovered from symptomatic plants was determined by sequencing a portion of TEF1. Because uninoculated seedlings did not develop malformation symptoms, and Fusarium spp. were not recovered from the mock-inoculated negative controls, plants did not appear to be latently infected with these pathogens prior to inoculation. The experiment was conducted twice.

\section{Results}

Big-leaf mahogany vegetative malformation symptomatology. Of the 280 big-leaf mahogany trees that were inspected at four sites in Michoacán, Mexico, malformation symptoms were observed on terminal and lateral vegetative shoots (Fig. 2) of 49 trees. All of the trees were located near commercial mango orchards in which some of the trees exhibited symptoms of MMD. Numerous affected buds occurred on lateral shoots inside the canopy of symptomatic big-leaf mahogany trees; the buds increased in size and later developed into a mass of tissue from which numerous small ramifications emerged with shortened internodes, deformed dwarfed leaves, and, occasionally, a few normal leaves. Initially, malformed tissues were green but later turned dark brown, necrotic, and woody. Floral malformation was not observed.

Genotyping of Fusarium isolates associated with big-leaf mahogany malformation disease. Oligonucleotides 809 and 891 each produced 10 unique bands, while those for oligonucleotide 812 produced 8 bands. Species-specific banding patterns were obtained for

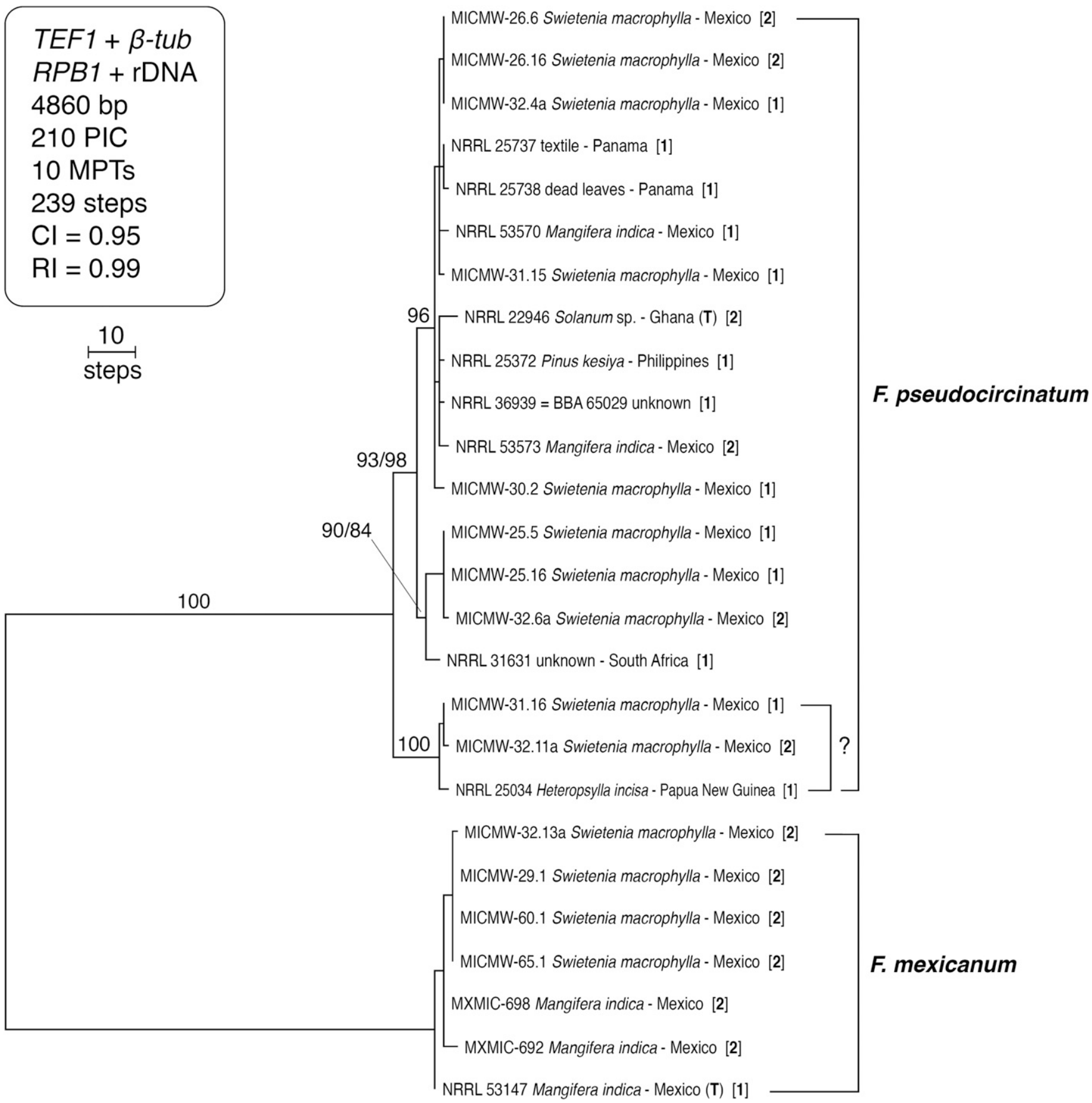

Fig. 3. One of 10 most-parsimonious trees (MPT) inferred from a four-locus dataset rooted at the midpoint. Maximum-likelihood bootstrap values (ML-BS) $\geq 70 \%$ are indicated above key nodes based on 1,000 pseudoreplicates of the data. The maximum-parsimony bootstrap (MP-BS) score is only shown when it differed from the ML value by $>5 \%$ (MLBS/MP-BS). Results of the polymerase chain reaction assay for MAT1-1 (1) and MAT1-2 (2) idiomorph are mapped on the phylogeny. BBA = Biologische Bundesanstalt für Landund Forstwirtschaft, Institut für Mikrobiologie, Berlin, Germany; $\mathrm{Cl}=$ consistency index; MICMW and MXMIC = Fungal Collection, Laboratorio de Patología Vegetal, Universidad Michoacana de San Nicolás de Hidalgo; NRRL = Agricultural Research Service Culture Collection, Peoria, IL; TEF1 = translation elongation factor 1- $\alpha ; \beta$-tub $=\beta$-tubulin; RPB1 = RNA polymerase largest subunit; PIC = parsimony informative characters; $R I=$ retention index; and $T=$ ex-type strain. 
F. mangiferae, F. mexicanum, F. pseudocircinatum, F. sterilihyphosum, and $F$. tupiense (Supplementary Fig. S1). The ISSR analysis indicated that 121 of the isolates were $F$. pseudocircinatum and 39 were $F$. mexicanum; the remaining three isolates appeared to represent distinct species.

Molecular phylogenetics. BLASTn searches of Fusarium MLST (http://www.westerdijkinstitute.nl/fusarium/), using the partial TEF1 sequences as the query, supported the ISSR identifications that indicated that 121 isolates were $F$. pseudocircinatum and 39 were $F$. mexicanum. In addition, isolates MICMW-32.6b and MICMW$32.8 \mathrm{~b}$ were nested within the $F$. incarnatum-equiseti species complex (FIESC) and MICMW-30.1 was a member of the $F$. solani species complex (FSSC). Previously published three-locus schemes for the FIESC (O'Donnell et al. 2009) and FSSC (O'Donnell et al. 2008) revealed that MICMW-32.6b and MICMW-32.8b were Fusarium sp. FIESC 20-d and FIESC 37-a, respectively, and MICMW-30.1 was Fusarium sp. FSSC 25-m. To assess whether the isolates identified as $F$. pseudocircinatum and $F$. mexicanum via ISSR were correctly identified, 16 of the mahogany isolates were subjected to a four-locus molecular phylogenetic analysis that included the extype strains of $F$. pseudocircinatum NRRL 22946 and $F$. mexicanum NRRL 53147 together with 10 previously characterized isolates of these species. MP and ML molecular phylogenetic analyses of the four individual and combined dataset confirmed the identifications obtained using ISSR data (Fig. 3).

MAT idiomorph. MAT1-1 and MAT1-2 idiomorphs were detected in the 19 isolates of $F$. pseudocircinatum and 7 isolates of $F$. mexica$n u m$ that were assayed. Four isolates of $F$. mexicanum recovered from big-leaf mahogany in Michoacán were all MAT1-2, as well as two isolates obtained from mango. Typing of the $19 \mathrm{~F}$. pseudocircinatum
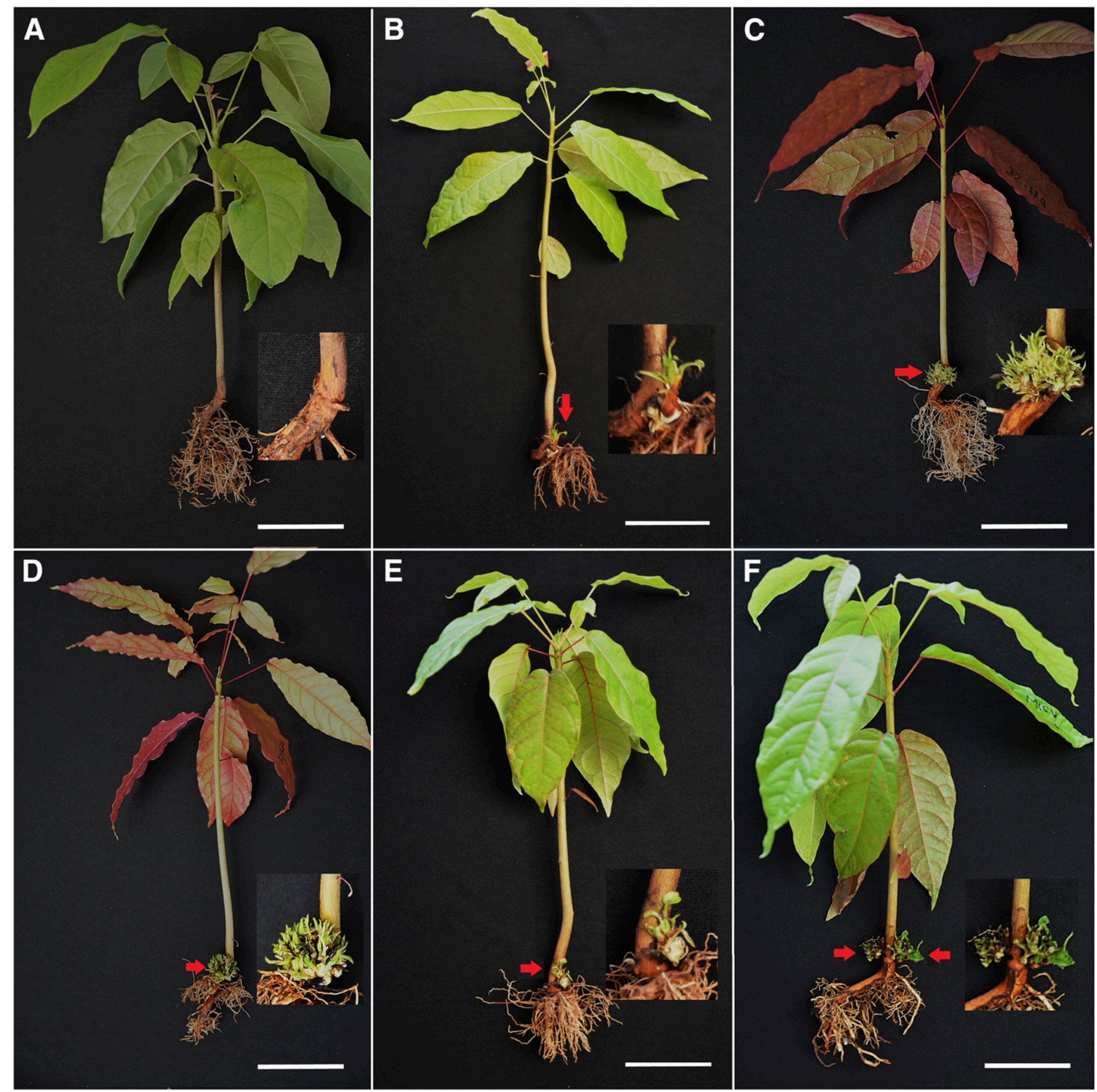

Fig. 4. Big-leaf mahogany seedlings exhibiting malformation symptoms 112 days after being inoculated. A, Sterile distilled water negative control. B, Inoculated with Fusarium pseudocircinatum MICMW-30.2. C, Inoculated with F. pseudocircinatum MICMW-32.11a. D, Inoculated with F. mexicanum MICMW-32.13a. E, Inoculated with F. mexicanum MICMW-65.1. F, Inoculated with F. mexicanum MXMIC-698. Arrows indicate malformed vegetative shoots. $B a r=5 \mathrm{~cm}$. Inset $=\times 3$. 
isolates revealed that 12 were $M A T 1-1$ and 6 were $M A T 1-2$; however, MAT idiomorph of NRRL 25738 could not be determined. Of the seven $F$. mexicanum screened, only the ex-type strain NRRL 53147 from Michoacán was MAT1-1.

Pathogenicity tests on big-leaf mahogany seedlings. Symptoms of malformed tissues on inoculated big-leaf mahogany seedlings were observed as early as 4 weeks after inoculation, but only in the crown (Fig. 4). F. pseudocircinatum isolates from big-leaf mahogany in Gabriel Zamora (Fig. 4B and C) and Parácuaro induced malformation but three from Apatzingán did not. All of the isolates of F. mexicanum (Fig. 4D and E) recovered from big-leaf mahogany and two from mango (Soto-Plancarte et al. 2015) induced symptoms on bigleaf mahogany. Malformed buds that formed below the soil line were initially white but turned green as they grew above the soil line. New malformed buds continued to emerge up until the experiment was terminated 16 weeks postinoculation. Symptoms did not develop on the plants inoculated with the three unnamed phylospecies and negative controls (Table 1). Partial TEF1 sequence data, which are widely used to identify Fusarium spp. via BLASTn queries of Fusarium MLST (O'Donnell et al. 2010), confirmed that the isolates recovered from malformed tissues were the same as those used to inoculate plants, thereby completing Koch's postulates. Plants inoculated with the three unnamed phylospecies and control plants failed to develop symptoms.

\section{Discussion}

This is the first report of a new disease of big-leaf mahogany, malformation, and its causal agents, F. mexicanum and F. pseudocircinatum, which also cause MMD in Mexico. Koch's postulates were successfully completed with isolates of these species that were recovered from symptomatic trees from the following locations in Michoacán (Fig. 4B to F): F. mexicanum from Gabriel Zamora and La Huacana and $F$. pseudocircinatum from Gabriel Zamora and Parácuaro. Additionally, two MMD isolates of $F$. mexicanum from a previous study (Soto-Plancarte et al. 2015) also induced malformation symptoms on big-leaf mahogany seedlings. Some isolates of these two species induced symptoms on seedlings 4 weeks postinoculation (i.e., F. mexicanum MICMW-32.13a, MICMW-65.1, MXMIC-692, and MXMIC-698; and F. pseudocircinatum MICMW-32.11a), while others took 4 months to incite discernible disease.

Isolates of the three unnamed phylospecies (Fusarium spp. FIESC 20-d, FIESC 37-a, and FSSC 25-m) recovered from malformed bigleaf mahogany were not pathogenic in our study (Table 1). Species within the FIESC are typically reported incorrectly as $F$. equiseti in the phytopathological literature and in GenBank (O'Donnell et al. 2015), but the name $F$. equiseti should only be used for FIESC 14 based on multilocus sequencing of the ex-neotype strain, NRRL 26149 (= CBS 307.94). Similarly, the 60+ species in the FSSC are typically reported in research studies as $F$. solani, as recommended by Leslie and Summerell (2006); however, with its recent epitypification (Schroers et al. 2016), the name $F$. solani should only be used for phylospecies FSSC 5.

ML and MP bootstrapping of the four-locus dataset appeared to strongly support the genealogical exclusivity of $F$. pseudocircinatum, in that the 19 isolates of this species that were analyzed formed tight clusters in the individual $R P B 1$, ribosomal DNA, and $\beta$-tubulin gene trees (data not shown). However, it is worth noting that three strains of this species possessed unusually divergent TEF1 alleles (i.e., MICMW-31.16 and 32.11 a from big-leaf mahogany and NRRL 25034 from the Hemipteran Heteropsylla incisa from Papua New Guinea) (Fig. 3). Moreover, because the RPB2 alleles of seven of the $F$. pseudocircinatum isolates were highly divergent, this dataset was not included in the present study because they may be nonorthologous. These findings highlight the need for studies to determine whether the putative nonorthologous alleles are due to interspecific hybridization, as posited for fusaria farmed by ambrosia beetles within the $F$. solani species complex (Kasson et al. 2013) and trichothecene toxin-producing cereal pathogens within the $F$. graminearum species complex (O'Donnell et al. 2000). If hybrid introgression has occurred in $F$. pseudocircinatum, it may have been mediated by highly fertile female strains. This highlights the need to determine whether this pathogen is reproducing sexually on these hosts, which has practical implications for disease management, given that pathogens that recombine sexually are more likely to overcome host resistance than ones that only reproduce asexually (Covert et al. 2007; McDonald and Linde 2002).

We note similarities between the symptoms we report here and those attributed to $F$. decemcellulare Brick. The latter pathogen is found associated with galls on many subtropical and tropical trees (Alfieri et al. 1994), most notably mango (Ploetz 2003) and cacao (Theobroma cacao) (Ploetz 2007). The hemispherical galls on these hosts that develop at leaf nodes and at wounded areas on main branches or trunks comprise many small buds (green points), most of which may be lost as the gall ages (Hansen 1963; Ploetz 2003).

Results of the present study suggest that $F$. mexicanum is the main cause of mango malformation in Mexico. Because it has not been detected outside of this country (Betancourt-Resendes et al. 2012; Otero-Colina et al. 2010), we speculate that $F$. mexicanum was associated with a native plant in Mexico but made a host jump after mango was introduced from the Philippines during the late 16th century (Litz 2009). This hypothesis is supported by phylogenetic data that place $F$. mexicanum in the American clade (Otero-Colina et al. 2010) proposed by O'Donnell et al. (1998). Future pathogen surveys of native herbaceous and woody plants are needed to increase our understanding of the host range and geographic distribution of the big-leaf mahogany pathogens, and shed light on the origins of these and other important pathogens of cultivated crops and trees.

Table 1. Pathogenicity tests on big-leaf mahogany seedlings using Fusarium strains associated with malformation disease in Michoacán, Mexico

\begin{tabular}{|c|c|c|c|c|}
\hline Fusarium spp. & Strain & Host & Collecting site & Inoculated plants with symptoms \\
\hline Fusarium sp. FIESC 37-a & MICMW-32.8b & Swietenia macrophylla & Gabriel Zamora & $0 / 10$ \\
\hline Fusarium sp. FIESC $20-\mathrm{d}$ & MICMW-32.6b & S. macrophylla & Apatzingán & $0 / 10$ \\
\hline Fusarium mexicanum & MICMW-32.13a & S. macrophylla & Gabriel Zamora & $4 / 10$ \\
\hline F. mexicanum & MICMW-60.1 & S. macrophylla & La Huacana & $3 / 10$ \\
\hline F. mexicanum & MICMW-65.1 & S. macrophylla & La Huacana & $6 / 10$ \\
\hline F. mexicanum & MXMIC-692z & Mangifera indica & Parácuaro & $4 / 10$ \\
\hline F. mexicanum & MXMIC-698z & M. indica & Parácuaro & $8 / 10$ \\
\hline F. pseudocircinatum & MICMW-26.6 & S. macrophylla & Parácuaro & $3 / 10$ \\
\hline F. pseudocircinatum & MICMW-32.11a & S. macrophylla & Gabriel Zamora & $2 / 10$ \\
\hline F. pseudocircinatum & MICMW-30.2 & S. macrophylla & Gabriel Zamora & $3 / 10$ \\
\hline F. pseudocircinatum & MICMW-25.5 & S. macrophylla & Apatzingán & $0 / 10$ \\
\hline F. pseudocircinatum & MICMW-25.16 & S. macrophylla & Apatzingán & $0 / 10$ \\
\hline F. pseudocircinatum & MICMW-32.6b & S. macrophylla & Apatzingán & $0 / 10$ \\
\hline Fusarium sp. FSSC $25-\mathrm{m}$ & MICMW-30.1 & S. macrophylla & Gabriel Zamora & $0 / 10$ \\
\hline
\end{tabular}

\footnotetext{
${ }^{\mathrm{y}}$ Measured at 112 days after inoculations.
}

${ }^{\mathrm{z}}$ Soto-Plancarte et al. (2015). 


\section{Acknowledgments}

We thank L. H. Pfenning for providing strains (Coleção Micológica de Lavras, Universidade Federal de Lavras, Lavras, Minas Gerais, Brazil); A. Reyes-Tena, A. C. Montoya-Martínez, and D. Pineda-Vaca for skilled technical assistance; and G. Doehring and N. Orwig for their skilled assistance in generating the DNA sequence data reported in this study.

\section{Literature Cited}

Abdalla, M. Y., Al-Rokibah, A., Moretti, A., and Mulè, G. 2000. Pathogenicity of toxigenic Fusarium proliferatum from date palm in Saudi Arabia. Plant Dis. 84: 321-324.

Alfieri, S. A., Jr., Langdon, K. R., Kimbrough, J. W., El-Gholl, N. E., and Wehlburg, C. 1994. Diseases and Disorders of Plants in Florida. Bull. No. 14. Division of Plant Industry, Gainesville, FL.

Betancourt-Resendes, I., Velázquez-Monreal, J. J., Montero-Castro, J. C., Fernández-Pavía, S. P., Lozoya-Saldaña, H., and Rodríguez-Alvarado, G. 2012. Fusarium mexicanum causal agent of mango malformation in Jalisco, Mexico. Rev. Mex. Fitopatol. 30:115-127.

Britz, H., Steenkamp, E. T., Coutinho, T. A., Wingfield, B. D., Marasas, W. F. O., and Wingfield, M. J. 2002. Two new species of Fusarium section Liseola associated with mango malformation. Mycologia 94:722-730.

Cohen, Y., Belausov, E., Maymon, M., Elazar, M., Shulman, I., Saada, D., Shtienberg, D., and Freeman, S. 2017. Fusarium mangiferae localization in planta during initiation and development of mango malformation disease. Plant Pathol. 66:924-933.

CONAFOR. 2017. Online publication. http://www.conafor.gob.mx/web/temasforestales/plantaciones-forestales/

Covert, S. F., Aoki, T., O’Donnell, K., Starkey, D., Holliday, A., Geiser, D. M., Cheung, F., Town, C., Strom, A., Juba, J., Scandiani, M., and Yang, X. B. 2007. Sexual reproduction in the soybean sudden death syndrome pathogen Fusarium tucumaniae. Fungal Genet. Biol. 44:799-807.

Crespo, M., Arrebola, E., Cazorla, F. M., Maymon, M., Freeman, S., Aoki, T., O’Donnell, K., Torés, J. A., and de Vicente, A. 2016. Analysis of genetic diversity of Fusarium tupiense, the main causal agent of mango malformation disease in southern Spain. Plant Dis. 100:276-286.

Elmer, W. H. 1995. A single mating population of Gibberella fujikuroi (Fusarium proliferatum) predominates in asparagus fields in Connecticut, Massachusetts, and Michigan. Mycologia 87:68-71.

Farr, D. F., Bills, G. F., Chamuris, G. P., and Rossman, A. Y. 1989. Fungi on Plants and Plant Products in the United States. American Phytopathological Society, St. Paul, MN.

Freeman, S., Otero-Colina, G., Rodríguez-Alvarado, G., Fernández-Pavía, S., Maymon, M., Ploetz, R. C., Aoki, T., and O'Donnell, K. 2014a. First report of mango malformation disease caused by Fusarium pseudocircinatum in Mexico. Plant Dis. 98:1583.

Freeman, S., Shtienberg, D., Maymon, M., Levin, A. G., and Ploetz, R. C. 2014b. New insights into mango malformation disease epidemiology lead to a new integrated management strategy for subtropical environments. Plant Dis. 98: 1456-1466.

García-López, E., Mora-Aguilera, J. A., Nava-Díaz, C., Villegas-Monter, A., Tovar-Pedraza, J. M., Serra, C., and Batista-Marte, C. M. 2016. First report of Fusarium pseudocircinatum causing mango malformation disease in Dominican Republic. Plant Dis. 100:1501.

Gardes, M., and Bruns, T. D. 1993. ITS primers with enhanced specificity for basidiomycetes: Application to the identification of mycorrhizae and rusts. Mol. Ecol. 2:113-118.

Gillies, A. C. M., Navarro, C., Lowe, A. J., Newton, A. C., Hernandez, M., Wilson, J., and Cornelius, J. P. 1999. Genetic diversity in Mesoamerican populations of mahogany (Swietenia macrophylla), assessed using RAPDs. Heredity 83: 722-732.

Grogan, J., and Barreto, P. 2005. Big-leaf mahogany on CITES Appendix II: Big challenge, big opportunity. Conserv. Biol. 19:973-976.

Hansen, A. J. 1963. The role of Fusarium decemcellulare and Fusarium roseum in the green-point cushion gall complex of cacao. Turrialba 13:80-87.

INEGI. 2009. Online publication. http://www3.inegi.org.mx/contenidos/app/ mexicocifras/datos_geograficos/16/16006.pdf

Kasson, M. T., O’Donnell, K., Rooney, A. P., Sink, S., Ploetz, R. C., Ploetz, J. N., Konkol, J. L., Carrillo, D., Freeman, S., Mendel, Z., Smith, J. A., Black, A. W., Hulcr, J., Bateman, C., Stefkova, K., Campbell, P. R., Geering, A. D. W., Dann, E. K., Eskalen, A., Mohotti, K., Short, D. P. G., Aoki, T., Fenstermacher, K. A., Davis, D. D., and Geiser, D. M. 2013. An inordinate fondness for Fusarium: Phylogenetic diversity of fusaria cultivated by ambrosia beetles in the genus Euwallacea on avocado and other plant hosts. Fungal Genet. Biol. 56:147-157.

Leslie, J. F., and Summerell, B. A., eds. 2006. The Fusarium Laboratory Manual. Blackwell Publishing, Ames, IA.

Lima, C. S., Pfenning, L. H., Costa, S. S., Abreu, L. M., and Leslie, J. F. 2012. Fusarium tupiense sp. nov., a member of the Gibberella fujikuroi complex that causes mango malformation in Brazil. Mycologia 104:1408-1419.

Litz, R. E. 2009. Mango. Pages 163-174 in: Compendium of Transgenic Crop Plants: Transgenic Tropical and Subtropical Fruits and Nuts, Part 5. C. Kole and T. C. Hall, eds. Blackwell Publishing, Ames, IA.
Liu, F., Weia, J., Zhan, R., Oub, X., and Chang, J. 2014. Genetic diversity of Fusarium mangifera isolated from mango malformation disease in China. Sci. Hortic. (Amsterdam) 165:352-356.

Logrieco, A., Moretti, A., Ritieni, A., Bottalico, A., and Corda, P. 1995 Occurrence and toxigenicity of Fusarium proliferatum from preharvest maize ear rot, and associated mycotoxins, in Italy. Plant Dis. 79:727-731.

Mayhew, J. E., and Newton, A. C. 1998. The Silviculture of Mahogany. CABI Publishing, Oxford. Wallingford, UK.

McDonald, B. A., and Linde, C. 2002. Pathogen population genetics, evolutionary potential, and durable resistance. Annu. Rev. Phytopathol. 40:349-379.

Navarro, C., Wilson, J., Gillies, A., and Hernández, M. 2003. A new Mesoamerican collection of big-leaf mahogany. Pages 103-114 in: Big Leaf Mahogany: Genetics, Ecology and Management. Ecological Studies, Vol. 159. A. E. Lugo, J. C. Figueroa, and M. Alayón, eds. Springer, New York.

Nirenberg, H. I., and O'Donnell, K. 1998. New Fusarium species and combinations within the Gibberella fujikuroi species complex. Mycologia 90: 434-458.

Ocamb, C. M., Juzwik, J., and Martin, F. B. 2002. Fusarium spp. and Pinus strobus seedlings: Root disease pathogens and taxa associated with seed. New For. 24: 67-79.

O’Donnell, K., and Cigelnik, E. 1997. Two divergent intragenomic rDNA ITS2 types within a monophyletic lineage of the fungus Fusarium are nonorthologous. Mol. Phylogenet. Evol. 7:103-116.

O’Donnell, K., Cigelnik, E., and Nirenberg, H. I. 1998. Molecular systematics and phylogeography of the Gibberella fujikuroi species complex. Mycologia 90:465-493.

O'Donnell, K., Kistler, H. C., Tacke, B. K., and Casper, H. H. 2000. Gene genealogies reveal global phylogeographic structure and reproductive isolation among lineages of Fusarium graminearum, the fungus causing wheat scab. Proc. Natl. Acad. Sci. U.S.A. 97:7905-7910.

O’Donnell, K., Sutton, D. A., Fothergill, A., McCarthy, D., Rinaldi, M. G., Brandt, M. E., Zhang, N., and Geiser, D. M. 2008. Molecular phylogenetic diversity, multilocus haplotype nomenclature, and in vitro antifungal resistance within the Fusarium solani species complex. J. Clin. Microbiol. 46:2477-2490.

O'Donnell, K., Sutton, D. A., Rinaldi, M. G., Gueidan, C., Crous, P. W., and Geiser, D. M. 2009. Novel multilocus sequence typing scheme reveals high genetic diversity of human pathogenic members of the Fusarium incarnatum$F$. equiseti and $F$. chlamydosporum species complexes within the United States. J. Clin. Microbiol. 47:3851-3861.

O’Donnell, K., Sutton, D. A., Rinaldi, M. G., Gueidan, C., Sarver, B. A. J., Balajee, S. A., Schroers, H.-J., Summerbell, R. C., Robert, V. A. R. G., Crous, P. W., Zhang, N., Aoki, T., Jung, K., Park, J., Lee, Y.-H., Kang, S., Park, B., and Geiser, D. M. 2010. Internet-accessible DNA sequence database for identifying fusaria from human and animal infections. J. Clin. Microbiol. 48: 3708-3718.

O’Donnell, K., Ward, T. J., Robert, V. A. R. G., Crous, P. W., Geiser, D. M., and Kang, S. 2015. DNA sequence-based identification of Fusarium: Current status and future directions. Phytoparasitica 43:583-595.

Otero-Colina, G., Rodríguez-Alvarado, G., Fernández-Pavía, S., Maymon, M., Ploetz, R. C., Aoki, T. A., O'Donnell, K., and Freeman, S. 2010. Identification and characterization of a novel etiological agent of mango malformation disease in Mexico, Fusarium mexicanum sp. nov. Phytopathology 100: 1176-1184.

Pérez-Salicrup, D., and Esquivel, R. 2008. Tree infection by Hypsipyla grandella in Swietenia macrophylla and Cedrela odorata (Meliaceae) in Mexico's southern Yucatan Peninsula. For. Ecol. Manage. 255:324-327.

Ploetz, R. C. 2001. Malformation: A unique and important disease of mango, Mangifera indica L. Pages 233-247 in: Fusarium: Paul E. Nelson Mem. Symp. B. A. Summerell, J. F. Leslie, D. Backhouse and W. L. Bryden, eds American Phytopathological Society, St Paul, MN

Ploetz, R. C. 2003. Diseases of mango. Pages 327-363 in: Diseases of Tropical Fruit Crops. R. C. Ploetz, ed. CAB International, Wallingford, UK.

Ploetz, R. C. 2007. Cacao diseases: Important threats to chocolate production worldwide. Phytopathology 97:1634-1639.

Ploetz, R. C., and Freeman, S. 2009. Foliar, Floral and Soilborne Diseases. Pages 231-302 in: The Mango. Botany, Production and Uses, 2nd ed. R. E. Litz, ed. CAB International, Homestead, FL.

Rodan, B. D., Newton, A. C., and Verissimo, A. 1992. Mahogany conservation: Status and policy initiatives. Environ. Conserv. 19:331-338.

Rodríguez-Alvarado, G., Betancourt-Resendes, I., Rodríguez-Fernández, R., Velázquez-Monreal, J. J., Fernández-Pavía, S. P., and Gómez-Dorantes, N. 2012. Vegetative compatibility groups characterization of Fusarium mexicanum causing mango malformation in Jalisco, Mexico. Rev. Mex. Fitopatol. 30: 128-140.

Rodríguez-Alvarado, G., Fernández-Pavía, S. P., Ploetz, R. C., and ValenzuelaVázquez, M. 2008. A Fusarium sp. different from Fusarium oxysporum and F. mangiferae is associated with mango malformation in Michoacán, Mexico. Plant Pathol. 57:781.

Schroers, H.-J., Samuels, G. J., Zhang, N., Short, D. P. G., Juba, J., and Geiser, D. M. 2016. Epitypification of Fusisporium (Fusarium) solani and its assignment to a common phylogenetic species in the Fusarium solani species complex. Mycologia 108:806-819. 
Senghor, A. L., Sharma, K., Kumar, P. L., and Bandyopadhyay, R. 2012. First report of mango malformation disease caused by Fusarium tupiense in Senegal. Plant Dis. 96:1582.

Soto-Plancarte, A., Santillán-Mendoza, R., Fernández-Pavía, S. P., Ploetz, R. C., Freeman, S., Ortega-Arreola, R., Osuna-Ávila, P., Velázquez-Monreal, J. J., and Rodríguez-Alvarado, G. 2015. Mango nurseries as sources of Fusarium mexicanum, cause mango malformation disease in central western Mexico. Phytoparasitica 43:427-435.

Steenkamp, E. T., Wingfield, B. D., Coutinho, T. A., Zeller, K. A., Wingfield, M. J., Marasas, W. F. O., and Leslie, J. F. 2000. PCR-based identification of MAT-1 and MAT-2 in the Gibberella fujikuroi species complex. Appl. Environ. Microbiol. 66:4378-4382.
Swofford, D. L. 2003. PAUP*. Phylogenetic Analysis Using Parsimony (*and Other Methods), version 4.0b10. Sinauer Associates, Sunderland, MA.

White, T. J., Bruns, T., Lee, S., and Taylor, J. 1990. Amplification and direct sequencing of fungal ribosomal RNA genes for phylogenetics. Pages 315-322 in: PCR Protocols: A Guide to Methods and Applications. M. A. Innes, D. H Gelfand, J. J. Sninsky, and T. J. White, eds. Academic Press, San Diego, CA.

Zhan, R. L., Yang, S. J., Ho, H. H., Liu, F., Zhao, Y. L., Chang, J. M., and He, Y. B. 2010. Mango malformation disease in south China caused by Fusarium proliferatum. J. Phytopathol. 158:721-725.

Zwickl, D. J. 2006. Genetic algorithm approaches for the phylogenetic analysis of large biological sequence data sets under the maximum likelihood criterion GARLI 2.01. Online publication. https://www.phylo.org 